\title{
Analisis Nilai Penting 40 Gua Prasejarah Di Maros, Sulawesi Selatan ${ }^{1}$
}

\author{
Muhammad Nur \\ Jurusan Arkeologi, Fakultas Ilmu Budaya, \\ Universitas Hasanuddin \\ Email:mnur@unhas.ac.id
}

\begin{abstract}
Abstrak : Fokus penelitian ini adalah menguji cara analisis nilai penting pada gua prasejarah. Tujuannya untuk menemukan penjelasan akademik dalam membedakan satu gua dengan gua lain. Pemilihan tema dilakukan karena perlunya alasan akademik untuk menentukan gua yang diprioritaskan dalam proses pelestarian dan pemanfaatan. Metode yang digunakan adalah pengumpulan data setiap gua, menentukan nilai penting, menyusun kriteria serta pembuatan penilaian dengan angka. Variabel nilai penting yang digunakan ada tujuh yaitu nilai penting sejarah, arkeologi, ekologi, speleogenesis, etnik, estetik dan publik. Dari 40 gua prasejarah di kompleks Leang-Leang Maros yang dianalisis, diperoleh hasil 18 gua dengan kategori nilai tinggi, 18 gua dengan kategori nilai sedang, dan 4 gua dengan kategori nilai rendah.
\end{abstract}

Kata kunci: leang, Maros, nilai penting, kriteria.

\begin{abstract}
The focus of this research is how to examine the significant value of prehistoric caves. The goal is to find an academic explanation to distinguishing one cave from another. The reason for choosing this theme is because academic reasonings are needed to determine priority caves in conservation and utilization process. The method used is data collecting from each cave, determination of significant values, compilation of criteria and conversion of judgments into numbers. There are seven criteria of significant value used, which are history, archaeology, ecology, speleogenesis, ethnic, aesthetic, and public value. There are 40 prehistoric caves in the Leangleang Maros complex that have been analysed, which consist of 18 caves with high value categories, 18 caves with middle value categories, and 4 caves with low value categories.
\end{abstract}

Keywords: leang, Maros, significant value, criteria

\section{Pendahuluan}

\section{A. Latar Belakang}

Analisis nilai penting [significance value] adalah tahapan yang harus dilakukan sebelum menentukan jenis peruntukan suatu situs cagar budaya atau kawasan cagar budaya. Karena pentingnya, banyak sarjana mengusulkan konsep untuk analisis nilai penting seperti Darvill (1995), Schiffer dan Gummerman (1977) atau Pearson, M. dan S. Sullivan (1995) dan banyak pula yang telah menerapkannya dalam penelitian seperti Nugroho (2006), Rustam Awat (2007), dan Supriadi (2008). Permasalahannya adalah data arkeologi di Indonesia sangat beragam sehingga sulit ditentukan satu model analisis nilai penting yang dapat digunakan untuk semua jenis situs atau kawasan. Keragaman cagar budaya kita dapat dilihat kompleksitasnya pada sisa hunian semisedentaire di gua-gua kapur, hunian pada situs-situs terbuka peninggalan Homo erectus dan komunitas
Austronesia, arsitektur bangunan keagamaan dan profan, variabilitas data arkeologi kubur, keragaman pemukiman kuno, kota kuno dan kota Kolonial, artefak efigrafi, artefak seni, data sejarah perbentengan serta sumberdaya arkeologi bawah air.

Konsekuensi saintifik dari keragaman cagar budaya tersebut adalah diperlukan beberapa model analisis nilai penting. Dengan mempertimbangkan pendapat para sarjana, dalam artikel ini akan didiskusikan satu model analisis nilai penting terhadap gua prasejarah, dan akan diujikan pada 40 situs gua prasejarah dari masa Plestosen Akhir dan pertengahan Holosen di kompleks gua prasejarah Leang-leang, Maros, Sulawesi Selatan.

Hipotesis yang diajukan adalah setiap situs gua prasejarah memiliki kandungan nilai penting yang berbeda. Dengan mengetahui perbedaan nilai penting setiap situs gua prasejarah tersebut, langkah dan prioritas pengelolaan dapat ditentukan secara efektif mengingat para pelestari 
cagar budaya sering dibatasi oleh dana, waktu maupun sumberdaya manusia.

Dalam perspektif tersebut, identifikasi tinggi rendahnya nilai penting setiap gua merupakan acuan metodologis dalam penentuan konsep, langkah teknis, serta pengelolaan satu situs gua. Tujuan paper ini adalah :

1. Menguji hipotesis yang diajukan dengan kriteria tertentu.

2. Menguji satu cara analisis dalam menduga nilai penting satu gua, bukan satu kawasan situs. Gagasan ini dikemukakan sebab sampai sekarang, belum pernah diterapkan suatu cara analisis untuk melihat kandungan dan perbedaan nilai penting setiap situs gua dalam satu kawasan situs gua-gua prasejarah di Sulawesi Selatan. Kajian yang ada selama ini adalah penentuan nilai penting untuk satu kawasan (Supriadi, 2008; Anonim, 1999; Anonim, 2001; Anonim, 2007a; b). Karena itu, meskipun perlakuan pengelolaan (pelestarian dan pemanfaatan) sudah dilakukan sejak tahun 1970-an pada gua-gua prasejarah di Sulawesi Selatan tetapi sampai sekarang belum memperlihatkan kemajuan manajemen pengelolaan. Belum adanya kajian nilai penting setiap gua menyebabkan seringnya digunakan pertimbangan non akademis dalam menentukan langkah-langkah pengelolaan.

\section{B. Metode}

Metode penelitian yang digunakan adalah survei secara bertahap yang dilakukan sejak 11 September 2008 sampai 12 Desember 2008. Sebelum survei lapangan, dilakukan studi pustaka yang menghasilkan format nilai penting yang terbagi dalam tujuh bagian yaitu nilai penting sejarah, arkeologi, ekologi, speleogenesis, etnik, estetik, dan publik, disertai dengan kriteria penilaiannya. Dalam penelitian lapangan, data yang berhubungan dengan potensi sejarah, arkeologi, ekologi, speleogenesis, etnik, estetik dan publik dari 40 situs dikumpulkan. Analisis ada dua bentuk yaitu pertama identifikasi bobot dari setiap

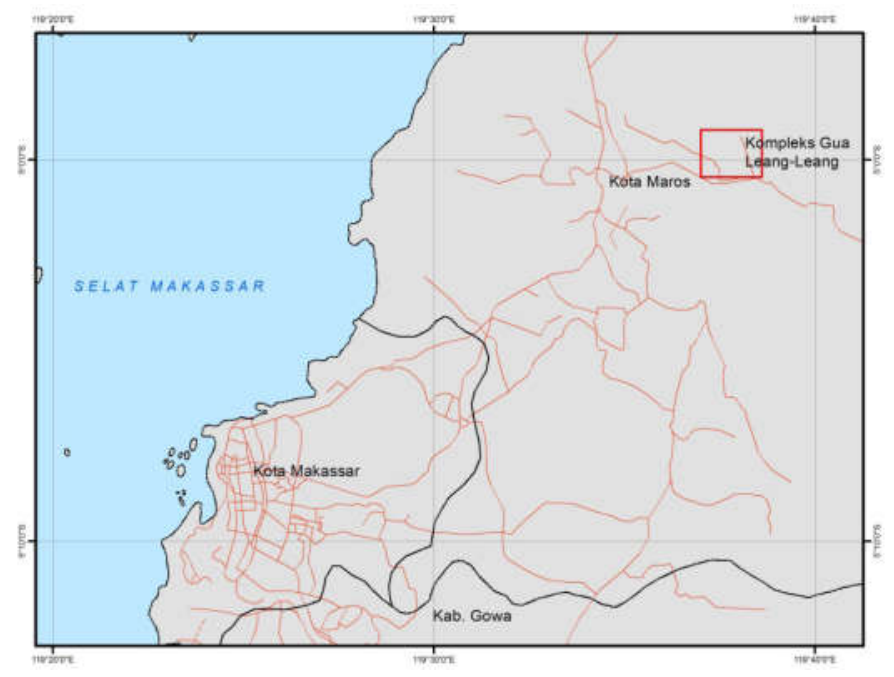

Peta 1. Letak kompleks gua Leang-leang, Maros, Sulawesi Selatan.

unsur nilai penting dalam satu gua, dan kedua menentukan akumulasi nilai penting setiap gua. Hasil analisis adalah suatu gambaran tentang bobot nilai penting setiap gua di Kompleks Prasejarah Leang-leang Maros.

\section{Pembahasan}

\section{A. Profil Lokasi Penelitian}

Kompleks Gua Leang-leang berada di kawasan pegunungan karst Kabupaten Maros, sebuah kawasan yang memiliki beragam sumberdaya, baik sumberdaya budaya maupun sumberdaya alam. Secara geologis, pegunungan karst tersebut termasuk dalam Formasi Tonasa. Kabupaten Maros berada pada koordinat antara $4^{\circ} 45^{\prime} 50^{\prime \prime}-4^{\circ} 55^{\prime} 00^{\prime \prime}$ LS dan $119^{\circ} 20^{\prime} 00^{\prime \prime}-119^{\circ} 54^{\prime}$ 00" BT dengan luas wilayah 1.613,11 $\mathrm{km}^{2}$, berbatasan dengan Kabupaten Pangkep di sebelah utara, dengan Kabupaten Bone di sebelah timur, dengan Kota Makassar dan Kabupaten Gowa di sebelah Selatan dan berbatasan dengan Selat Makassar di sebelah Barat. Terletak $\pm 35 \mathrm{~km}$ di sebelah Utara Kota Makassar, Kompleks Gua Leangleang mudah diakses, baik dengan kendaraan beroda dua maupun empat.

Lokasi penelitian adalah Kelurahan Leang-leang dan Kelurahan Kalabbirang di Kecamatan Bantimurung dan Desa Samanggi di Kecamatan Simbang. Dua kecamatan tersebut selain mengandung 40 buah gua

\footnotetext{
2Situs cagar budaya adalah lokasi yang berada di darat dan/atau di air yang mengandung benda cagar budaya, bangunan cagar budaya, dan/ atau struktur cagar budaya sebagai hasil kegiatan manusia atau bukti kejadian pada masa lalu [Anonim, 2012:4].

${ }^{3}$ Kawasan cagar budaya adalah satuan ruang geografis yang memiliki dua situs cagar budaya atau lebih yang letaknya berdekatan dan/atau memperlihatkan ciri tata ruang yang khas [Anonim, 2012:5].

${ }^{4}$ Pengertian gua prasejarah dalam artikel ini adalah gua yang mengandung artefak dari jaman prasejarah, baik di dalam lapisan tanahnya, permukaan tanah atau pada dinding gua.
} 
prasejarah, juga terdapat pemukiman masyarakat, Taman Wisata Air Terjun Bantimurung, Taman Nasional Bantimurung-Bulusaraung, dan lokasi hutan lindung.

Di lokasi penelitian, ada tiga jenis gua berdasarkan struktur geologinya, yaitu pertama, gua kekar tiang yang meliputi kelompok Gua Pattae, kelompok Gua Lambattorang dan kelompok Gua Bara Tedong. Kedua, gua kekar lembaran yang meliputi kelompok Leang Burung, kelompok Leang Barugayya dan kelompok Leang Pakalu. Ketiga adalah gabungan gua kekar tiang dan gua kekar lembaran meliputi kelompok Leang Sampeang dan kelompok Leang Ulu Wae.

Karakter sosial budaya masyarakat setempat mewakili dua karakter suku yang mengapitnya yaitu Suku Bugis dan Suku Makassar. Arsitektur rumah mereka adalah rumah panggung yang secara vertikal terbagi atas tiga bagian, yaitu bagian atas (rakkeang), bagian tengah (iase bola) dan bagian bawah (iawa bola).

Keterampilan bertani yang dimiliki diwariskan turun temurun dari pendahulunya. Masyarakat setempat yang bilingual dimungkinkan untuk lebih berwawasan luas dan terbuka terhadap iklim perubahan karena letaknya berbatasan dengan Kota Makassar yang merupakan kota transit dan kota pelabuhan sejak abad ke-17. Keberadaan Bandara Hasanuddin di Kab. Maros yang hanya berjarak sekitar $20 \mathrm{~km}$ dari lokasi penelitian turut membentuk watak masyarakatnya yang selalu siap dan terbuka menerima orang luar. Selain itu, kawasan karst Maros yang sejak 1905 telah terpublikasi sebagai lokasi yang menyimpan keunikan alam dan budaya, menjadikan lokasi penelitian ini sering dikunjungi oleh peneliti, baik domestik maupun peneliti asing. Mental masyarakat yang siap menerima perubahan dari luar inilah yang membedakannya dengan masyarakat di Sulawesi Selatan pada umumnya.

Agama Islam dianut oleh masyarakat secara ketat. Oleh karena itu, letak mesjid dapat dijumpai tidak berjauhan. Sebagai sistem religi, agama Islam sangat mempengaruhi banyak sistem kehidupan masyarakat misalnya perayaan kelahiran, kesuksesan, perkawinan, peringatan kematian, gaya hidup termasuk model pakaian. Bahkan agama Islam juga dijadikan motivasi untuk berkumpul misalnya kegiatan pengajian yang terjadwal.

\section{B. Nilai Penting dan Kriteria}

Ada banyak nilai penting yang dikandung oleh gua prasejarah. Dalam penelitian ini, nilai penting yang dapat diidentifikasi pada 40 sampel gua prasejarah di Maros ada tujuh yaitu sejarah, arkeologi, ekologi, speleogenesis, etnik, estetik dan publik.

1) Nilai penting sejarah yang dikandung satu gua dilihat dari kandungan datanya yang dapat mengungkap seri sejarah umat manusia. Rentang hunian manusia di kompleks gua Leang-leang dapat meliputi hunian periode praToala, hunian periode Toala maupun hunian periode Austronesia, sejak 100.000 tahun lalu [Brumm,2012:7] sampai awal Masehi. Setiap gua memiliki potensi data yang berbeda dalam mengungkap satu seri atau beberapa seri sejarah manusia.

2) Nilai penting arkeologi setiap gua tergambar dari temuan permukaan dan stratigrafi tanah yang mengandung sedimen budaya material. Temuan arkeologi yang pernah ditemukan oleh peneliti adalah kerang darat dan laut, artefak batu, alatalat tulang, tulang binatang, lukisan pada dinding gua, tembikar, manik-manik, rangka manusia, dan serbuk sari tumbuhan purba. Data arkeologi tersebut telah dan masih dapat dikaji untuk pengembangan ilmu arkeologi, dibuktikan oleh banyaknya penelitian yang pernah dilakukan (Sarasin, 1905; Heekeren, 1972;Glover, 1976\&1984; Di Lello, 2002; Hakim, dkk., 2009; Aubert, dkk.,2014; Duli dan Muhammad Nur, 2016).

3) Nilai penting ekologi setiap gua tergambar dari kekayaan ekosistem gua, baik ekosistem lantai gua maupun langit-langit gua. Ekosistem gua berpotensi melahirkan spesies baru seperti jenis udang tidak bermata yang banyak terdapat dalam sungai bawah tanah di kompleks gua-gua karts Maros. Keberadaan sungai bawah tanah, genangan air, dan kelelawar/walet merupakan indikator kunci dari nilai ekologis. Dalam Keputusan Menteri Energi dan Sumberdaya Mineral Nomor 1456 K/20/MEM/2000 tentang Pedoman Pengelolaan Kawasan Karst, kelelawar dan walet dinyatakan sebagai fauna kunci untuk ekosistem gua karena kotoran dan bangkainya menjadi makanan bagi organisma 
lain dalam ekosistem gua.

4) Nilai penting speleogenesis setiap gua tergambar dari kondisi pembentukan gua, yang terutama indikatornya dilihat dari tingkat keaktifan satu gua. Gua aktif adalah gua yang memiliki aliran sungai bawah tanah. Di pegunungan karst Maros, banyak gua yang masih mengalami proses pembentukan. Kekayaan speleogenesis ini adalah satu potensi yang harus diintegrasikan dengan potensi lain untuk dipertimbangkan sebagai satu variabel pemberi nilai terhadap satu gua.

5) Nilai penting etnik setiap gua ditunjukkan oleh jejak eksistensi komunitas Austronesia [ras Mongoloid] pada masa prasejarah di Sulawesi Selatan. Bukti arkeologis yang dimaksud adalah berupa fragmen beliung persegi, tembikar dan batu asah. Selain itu, dalam penggalian arkeologis di Leang Petta Kerre pada tahun 1978 berhasil ditemukan satu tengkorak manusia tanpa rangka dari ras Mongoloid. Menurut Simanjuntak [2008: 219], fenomena kedatangan komunitas Austronesia yang berciri ras Mongoloid di Pulau Sulawesi bukan hanya menjadi fenomena regional Asia Tenggara tetapi lebih luas sampai Pasifik. Bukti arkeologis tersebut merupakan salah satu bukti tertua tentang geneologi dan budaya dari etnik Bugis, Makassar, dan Toraja yang mendiami Sulawesi Selatan sekarang.

6) Nilai penting estetik setiap gua ditunjukkan oleh artefak lukisan dinding gua. Ada dua warna luksian yaitu merah dan hitam, sedangkan jenis lukisan dinding gua berupa lukisan babi rusa dengan mata panah menancap di bagian dada, cap tangan dalam beberapa variasi [cap telapak dan jari-jari, ada yang sampai pada lengan, ada yang jari-jarinya runcing serta ada yang jari-jarinya tidak lengkap], lukisan manusia menunggang kuda dan coretan abstrak yang belum teridentifikasi. Lukisan pada dinding gua [mural cave] di Kompleks Leang-leang merupakan salah satu bukti ekspresi seni tertua di Indonesia bahkan di dunia.

7) Nilai penting publik ditunjukkan oleh ketertarikan masyarakat terhadap satu gua, baik masyarakat ilmiah maupun awam. Nilai penting publik dapat memuaskan rasa penasaran masyarakat tentang beberapa aspek kehidupan manusia prasejarah dan lansekap alamnya yang menarik. Wujud dari nilai penting publik adalah aktivitas pariwisata, baik pariwisata massal maupun pariwisata minat khusus [Nur,2013]. Berdasarkan trend minat kunjung dan apresiasi masyarakat terhadap gua-gua prasejarah, data Dinas setempat menunjukkan peningkatan yang signifikan setiap tahun.

Setiap variabel dari tujuh variabel di atas yang memiliki nilai penting tinggi diberi bobot 3, jika memiliki nilai penting sedang diberi bobot 2 , dan nilai penting rendah diberi bobot 1. Adapun indikator dari bobot tujuh variabel nilai penting diuraikan sebagai berikut.

Satu gua akan diberi bobot nilai tinggi [nilai 3] untuk variabel nilai penting sejarah jika gua tersebut mengandung dua ciri budaya yang berbeda [budaya pra Austronesia dan budaya Austronesia] serta mengandung lukisan dinding gua. Sebuah gua diberi bobot sedang [nilai 2] jika mengandung satu ciri budaya dan mengandung lukisan dinding gua. Sebuah gua diberi bobot rendah [nilai 1] jika gua tersebut hanya mengandung satu ciri budaya dan atau hanya mengandung lukisan dinding gua saja.

Satu gua akan diberi bobot nilai tinggi [nilai 3] untuk variabel nilai penting arkeologi jika gua tersebut mengandung variabilitas artefak yang tinggi misalnya mengandung semented sisa makanan, artefak batu, tembikar, lukisan dinding gua dan jenis artefak lain. Sebuah gua diberi bobot sedang [nilai 2] jika gua tersebut mengandung variabilitas artefak yang tidak tinggi [hanya mengandung 2 jenis artefak] misalnya hanya ditemukan sisa makanan dan lukisan dinding gua. Sebuah gua diberi bobot rendah [nilai 1] jika gua tersebut hanya mengandung 1 jenis artefak misalnya hanya ditemukan lukisan dinding gua atau hanya ditemukan artefak batu saja.

Gua diberi bobot tinggi [nilai 3] untuk variabel 
nilai penting ekologi jika gua tersebut minimal memiliki : 1] sungai atau genangan air dalam gua dan 2]. memiliki komunitas langit-langit gua [kelelawar dan walet]. Sebuah gua diberi bobot sedang (nilai 2) jika gua tersebut hanya mengandung sungai atau genangan air dalam gua atau hanya mengandung komunitas langit-langit gua/komunitas lantai. Sebuah gua diberi bobot rendah [nilai 1] jika gua tersebut tidak memiliki sungai atau genangan dalam gua dan tidak memiliki komunitas langit-langit/komunitas lantai. Biasanya gua yang termasuk jenis ini hanya dipakai oleh biota luar gua untuk keperluan tertentu misalnya ular yang masuk ke gua untuk berganti kulit.

Gua diberi bobot tinggi [nilai 3] untuk variabel nilai penting speleogenesis jika gua tersebut merupakan gua aktif serta air masih merembes pada dinding dan langit-langit gua sehingga membentuk ornamen walaupun pada musim kemarau. Sebuah gua diberi bobot sedang [nilai 2] jika gua tersebut bukan gua aktif tetapi air masih merembes pada dinding dan langit-langit gua untuk membentuk ornamen walaupun pada musim kemarau. Sebuah gua diberi bobot rendah [nilai 1] jika gua tersebut bukan gua aktif dan proses perembesan air pada dinding dan langit-langit gua hanya terjadi pada musim hujan.

Gua diberi bobot tinggi [nilai 3] untuk variabel nilai penting etnik jika pertama, pada gua tersebut pernah ditemukan rangka manusia ras Mongoloid, dan kedua, gua tersebut memiliki artefak yang mencirikan kebudayaan Austronesia misalnya tembikar, beliung persegi, batu asah, dan alat batu yang sudah diasah. Sebuah gua diberi bobot sedang [nilai 2] jika pada gua tersebut ditemukan artefak yang mengindikasikan adanya bekas okupasi orang Austronesia misalnya tembikar, beliung persegi, batu asah dan alat batu yang sudah diasah. Sebuah gua diberi bobot rendah [nilai 1] jika pada gua tersebut ditemukan artefak kebudayaan Austronesia tetapi indikasinya tidak kuat, misalnya hanya ditemukan tembikar saja atau hanya ditemukan fragmen beliung persegi saja.

Gua diberi bobot tinggi [nilai 3] untuk variabel nilai penting estetis jika gua tersebut mengandung temuan lukisan dinding gua dalam bentuk yang beragam.
Sebuah gua diberi bobot sedang [nilai 2] jika gua tersebut mengandung lukisan dinding gua hanya satu jenis tetapi jumlahnya banyak. Sebuah gua diberi bobot rendah [nilai 1] jika gua tersebut hanya mengandung satu jenis lukisan dan dalam kondisi rusak sehingga sulit diidentifikasi atau tidak mengandung lukisan dinding gua sama sekali.

Gua diberi bobot tinggi [nilai 3] untuk variabel nilai penting publik jika gua tersebut mengandung 3 unsur yaitu pertama, temuan arkeologis yang beragam misalnya terdapat artefak batu, lukisan dinding gua dan lain-lain. Kedua, memiliki ornamen interior gua yang menarik, dan ketiga, lansekap sekitar gua yang menarik dan indah. Sebuah gua diberi bobot sedang [nilai 2] jika gua tersebut mengandung dua unsur yang disebutkan di atas. Sebuah gua diberi bobot rendah [nilai 1] jika gua tersebut hanya mengandung 1 unsur yang disebutkan di atas.

Langkah selanjutnya setelah penentuan bobot nilai penting setiap variabel pada setiap gua adalah menjumlah nilai semua variabel nilai penting yang dimiliki oleh sebuah gua. Akumulasi nilai yang dimiliki oleh sebuah gua dikategorikan lagi menjadi 3 kategori yaitu tinggi, sedang dan rendah. Gua yang termasuk kategori tinggi adalah gua yang memiliki akumulasi nilai 15 ke atas. Gua yang termasuk kategori sedang adalah gua yang memiliki akumulasi nilai 8-14, sedangkan gua yang memiliki akumulasi nilai 7 termasuk gua yang nilai pentingnya rendah.

\section{Data, Analisis, dan Hasil}

Data nilai penting dari 40 gua prasejarah Leang-leang sangat panjangdan tidak cukup ruang untuk memaparkannya pada media ini secara naratif. Dengan demikian, hanya analisis dan hasil analisis yang akan diuraikan. Potensi sejarah, arkeologis, ekologis, speleogenesis, etnik, estetik, dan publik yang dianalisis adalah data artefaktual dan lingkungan yang tampak dipermukaan, ditambah hasil riset yang pernah dilakukan oleh peneliti terdahulu. Jika dalam penelitian di masa mendatang ditemukan data tambahan, maka nilai penting tersebut dapat ditinjau ulang. Nilai penting memang

${ }^{6}$ Penelitian terakhir dengan metodepertanggalan Uranium series, menghasilkan tarikh minimum 39.9 ribu tahun untuk cap tangan di Leang Timpuseng, sedangkan gambar babirusa paling tidak bertarikh 35.4 ribu tahun, merupakan lukisan figuratif tertua di dunia hingga saat ini kalau bukan satu-satunya (Aubert, dkk.,2014:223).

${ }^{7}$ Dalam menganalisis artefak batu selama penelitian, rujukan yang paling banyak digunakan adalah Forestier (2007) dan William Andrefsky, Jr. (2008). 


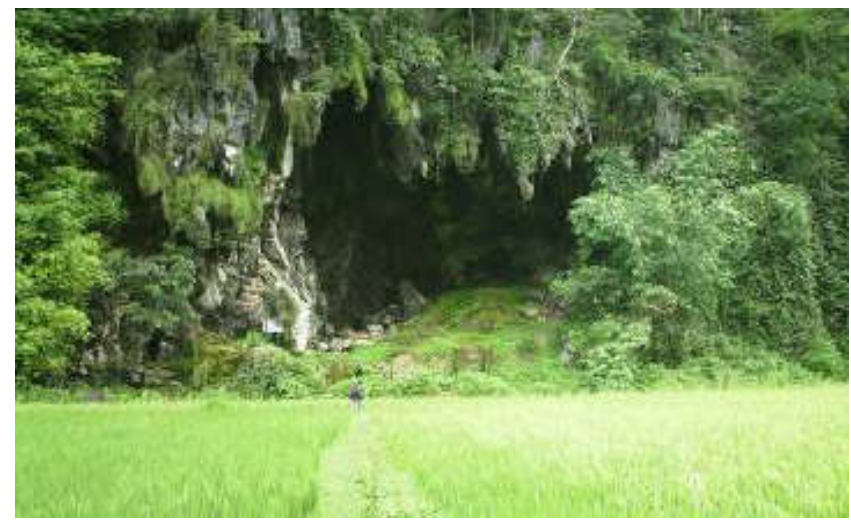

Foto 1. Kondisi Gua Tinggi Ada'

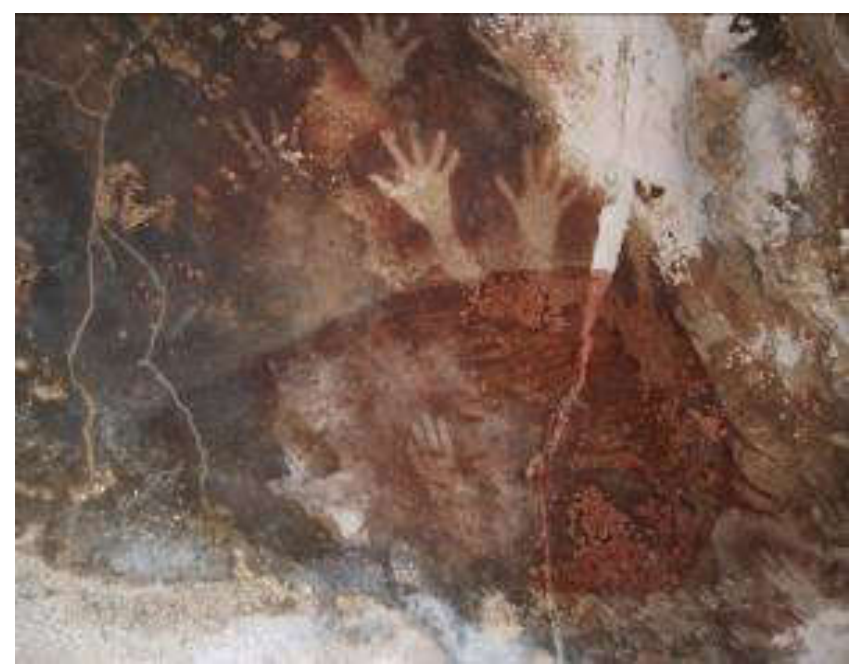

Foto 2. Lukisan babi yang dikelilingi cap tangan di Gua Pettakere.

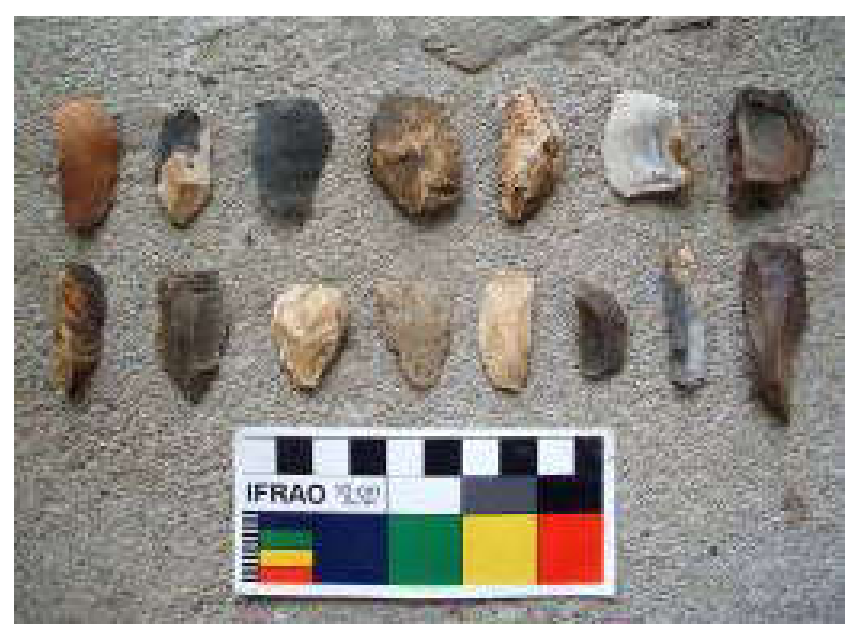

Foto 3. Artefak batu serpih dari Gua Lambattorang.

harus selalu ditinjau karena beberapa sebab misalnya adanya pemaknaan baru, penurunan kualitas sumberdaya

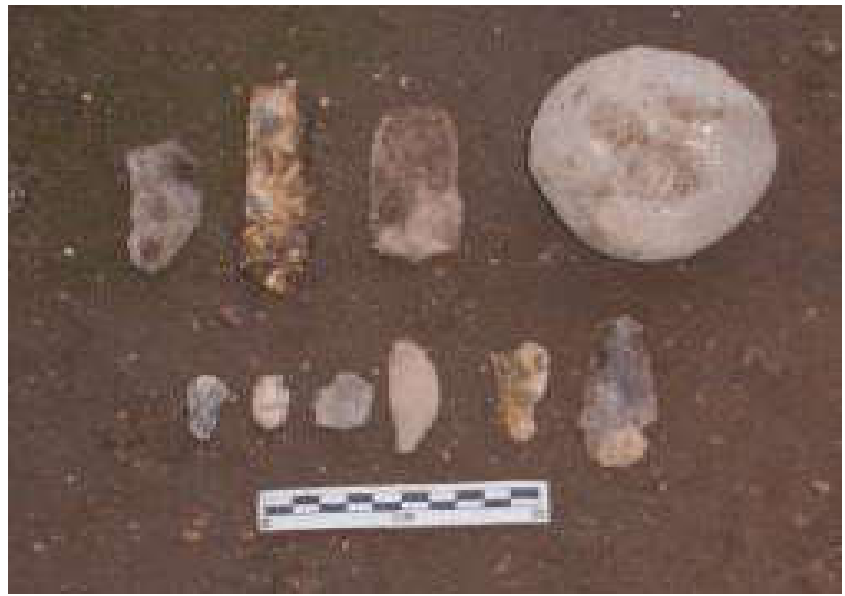

Foto 4. Palu batu, alat serpih dan calon beliung dari Gua Pajae.

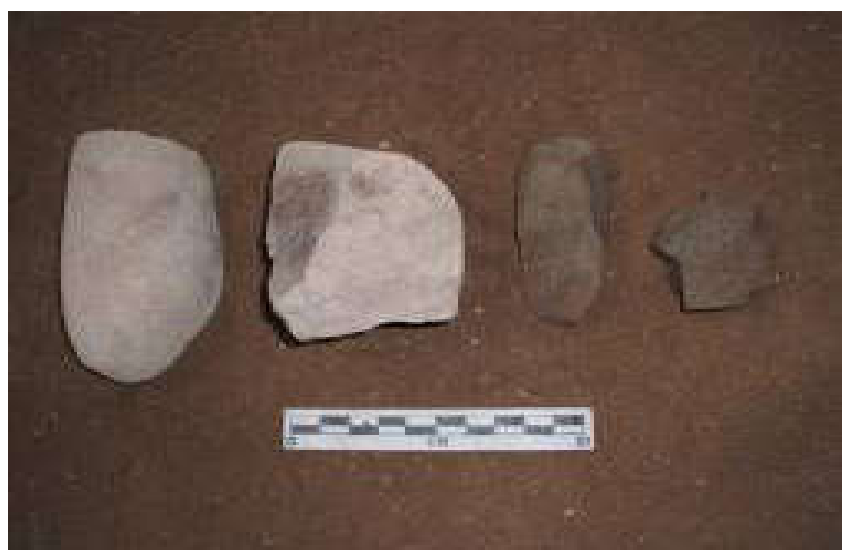

Foto 5. Pecahan batu asah dan alat batu sudah diupam di Gua Bembe.

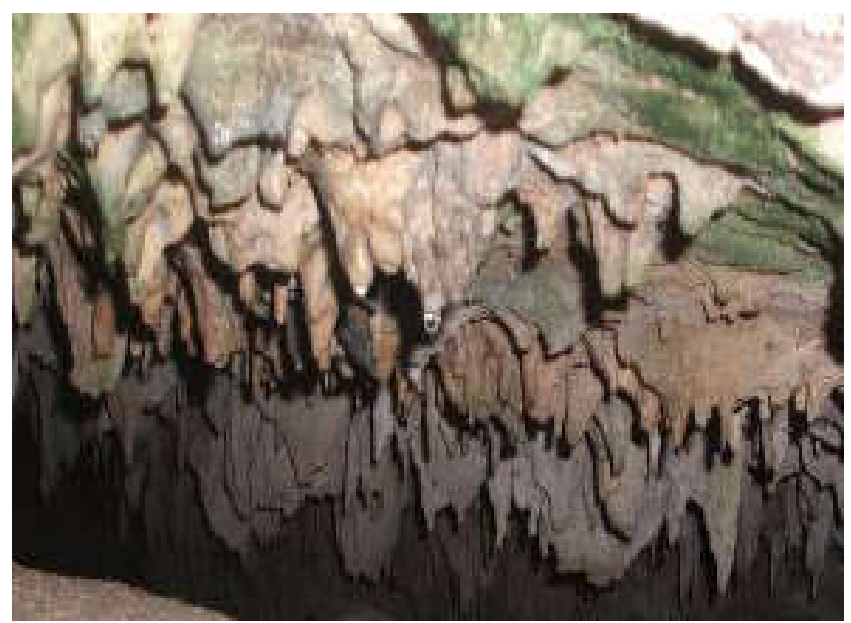

Foto 6. Jejeran stalaktit di dalam relung di Gua Balang.

arkeologi, atau adanya temuan baru hasil penelitian terkini. Upaya pendugaan nilai penting ini mendesak dilakukan

${ }^{8}$ Kelelawar dan walet adalah jenis fauna gua yang mempunyai nilai ekosistem tinggi. Baca KepMen Energi dan Sumberdaya Mineral Nomor 1456 K/20/MEM/2000 tentang Pedoman Pengelolaan Kawasan Karst. Untuk penjelasan pentingnya kelelawar dan walet dalam ekosistem gua, baca juga Whitten, dkk., 1987; Goodwin, 1979; Bullock, 1966; Odum, 1994; Nur ,2009.

${ }^{9} \mathrm{Gua}$ aktif adalah gua yang mempunyai aliran sungai bawah tanah. Gua tidak aktif atau gua fosil adalah gua kering yang kadang-kadang dibanjiri oleh air asal permukaan. [KepMen Energi dan Sumberdaya Mineral,2000:2]. 


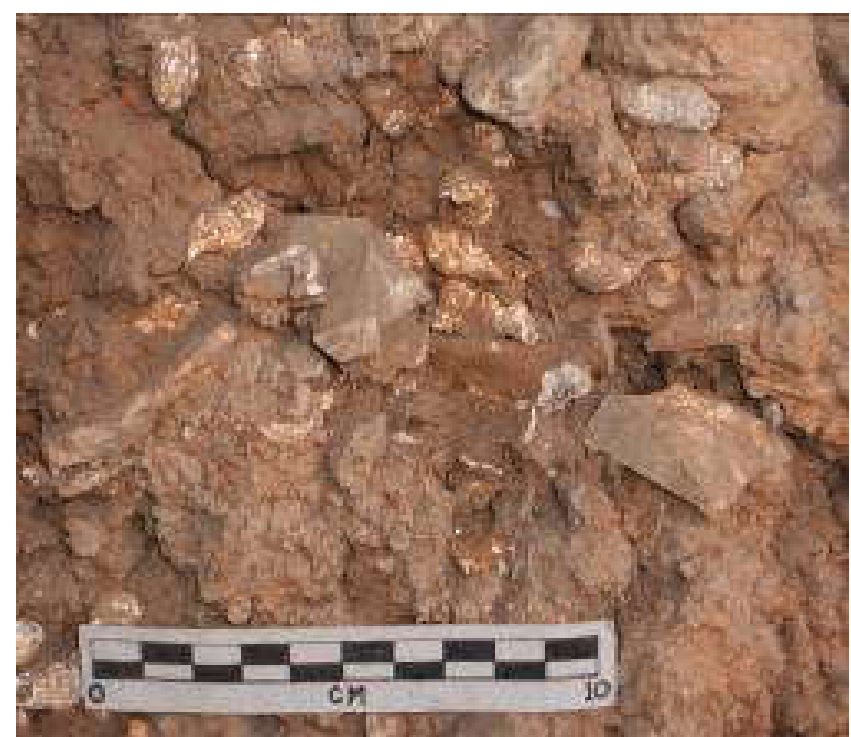

Foto 7. Deposit artefak batu dan kerang pada singkapan tanah di Gua Karrasa.

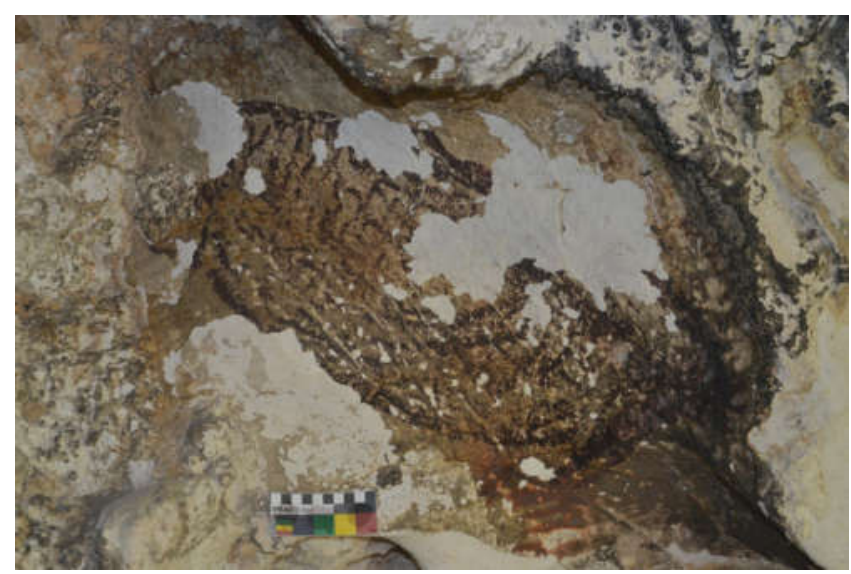

Foto 8. Lukisan anoa (fauna endemik Sulawesi) di Gua Bara Tedong

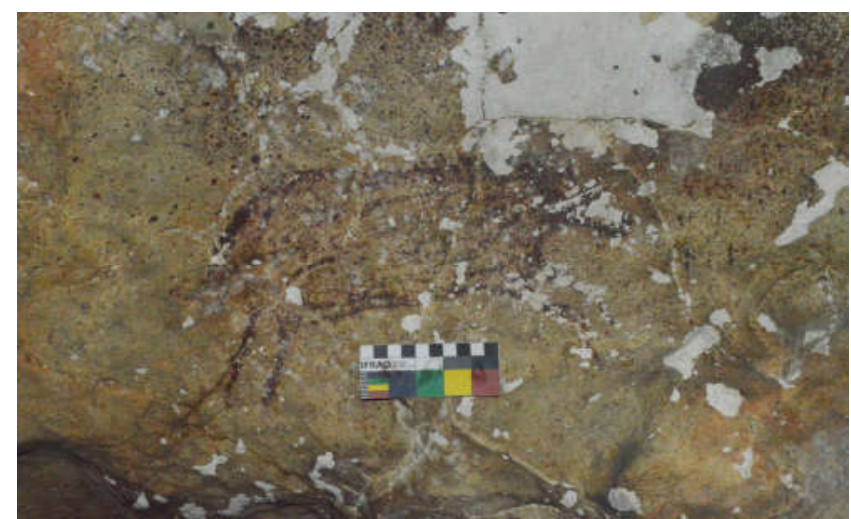

Foto 9. Lukisan babi di Gua Pattae.

mengingat alasan akademis sangat penting posisinya untuk efektivitas, efisiensi dan kepastian langkah-langkah pengelolaan. Termasuk dalam bingkai pengelolaan (management) sumberdaya arkeologi adalah konservasi arkeologi. Jadi di masa mendatang, upaya konservasi

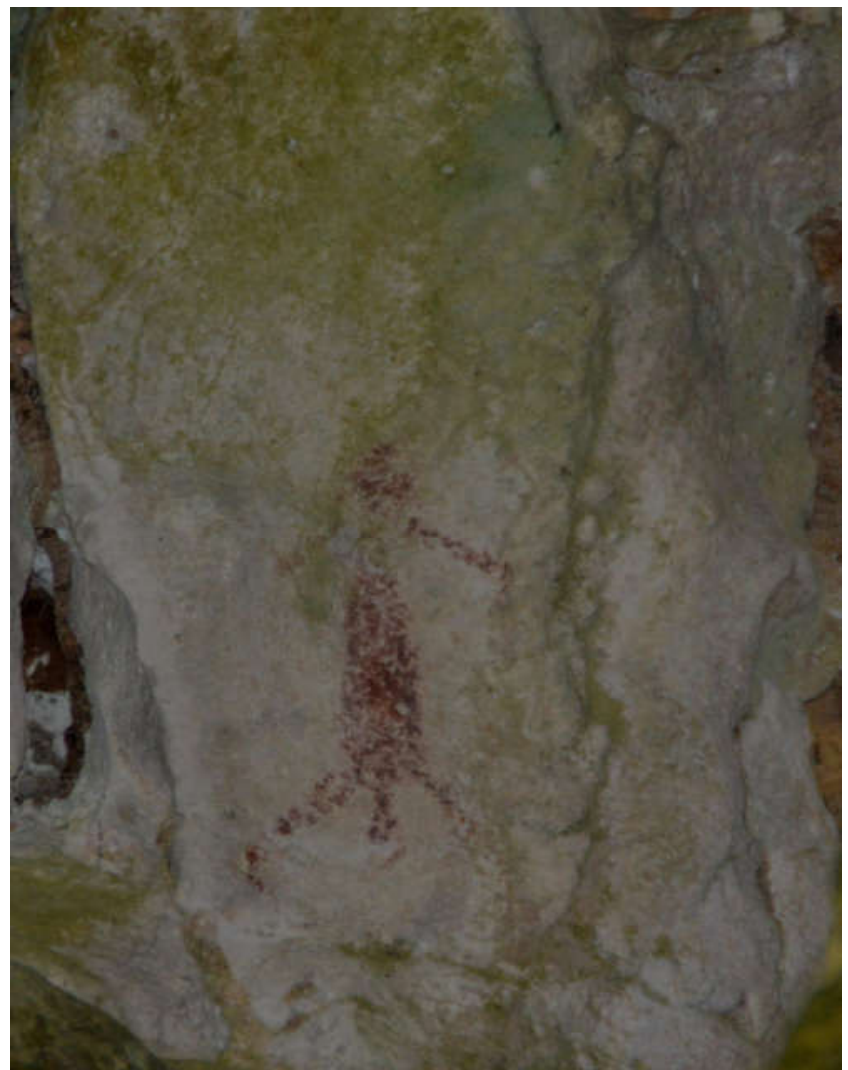

Foto 10. Lukisan manusia (laki-laki) di Gua Jarie dengan kemaluan menjuntai ke bawah.

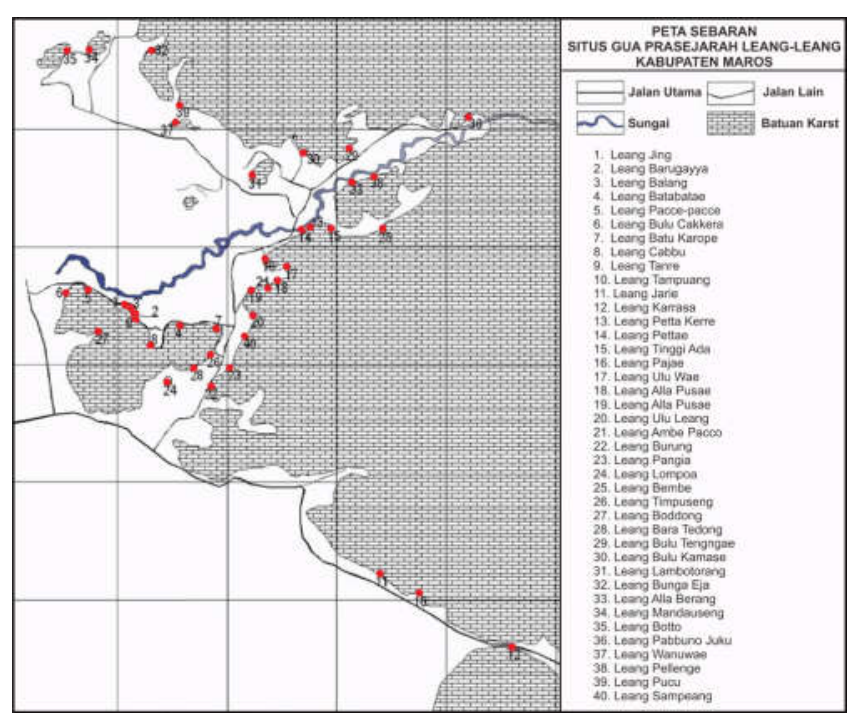

Peta 2. Sebaran 40 gua prasejarah yang dijadikan sampel penelitian.

bobot nilai penting gua yang berbeda antara satu gua dengan gua lainnya.

Hasil analisis nilai penting dari 40 situs gua prasejarah dengan memakai tujuh variabel penilaian ditampilkan dalam tabel 1.

Dari 40 gua prasejarah di Kompleks LeangLeang, gua yang termasuk kategori bernilai penting tinggi sebanyak 18 gua. Gua yang termasuk kategori bernilai 
Tabel 1. Hasil analisis nilai penting pada $\mathbf{4 0}$ situs gua prasejarah di Sulawesi Selatan.

\begin{tabular}{|c|c|c|c|c|c|c|c|c|c|}
\hline No & Nama gua & Sejarah & Ark & Eko & Spel & Etn & Este & Pub & Jumlah \\
\hline 1 & L. Jing & 3 & 3 & 2 & 2 & 1 & 3 & 3 & 17 \\
\hline 2 & L. Barugayya & 3 & 3 & 2 & 2 & 2 & 2 & 3 & 17 \\
\hline 3 & L. Balang & 1 & 2 & 3 & 3 & 1 & 1 & 2 & 13 \\
\hline 4 & L. Bata-batae & 2 & 2 & 1 & 1 & 1 & 2 & 1 & 10 \\
\hline 5 & L. Pacce-pacce & 1 & 1 & 1 & 1 & 1 & 1 & 1 & 7 \\
\hline 6 & L. Bulu Cakkera & 1 & 1 & 1 & 1 & 1 & 1 & 1 & 7 \\
\hline 7 & L. Batu Karopa & 3 & 3 & 2 & 2 & 2 & 1 & 2 & 15 \\
\hline 8 & L. Cabbu & 1 & 2 & 3 & 3 & 1 & 1 & 1 & 12 \\
\hline 9 & L. Tanre & 2 & 2 & 2 & 2 & 1 & 1 & 1 & 11 \\
\hline 10 & L. Tappuang & 3 & 3 & 3 & 2 & 1 & 3 & 3 & 18 \\
\hline 11 & L. Jarie & 3 & 3 & 2 & 2 & 1 & 2 & 3 & 16 \\
\hline 12 & L. Karrasa & 2 & 2 & 2 & 1 & 1 & 1 & 2 & 11 \\
\hline 13 & L. Petta Kerre & 3 & 3 & 1 & 2 & 3 & 3 & 3 & 17 \\
\hline 14 & L. Pattae & 3 & 3 & 2 & 2 & 1 & 3 & 2 & 16 \\
\hline 15 & L. Tinggi Ada & 3 & 3 & 2 & 2 & 1 & 1 & 2 & 14 \\
\hline 16 & L. Pajae & 3 & 3 & 2 & 2 & 2 & 2 & 3 & 17 \\
\hline 17 & L. Ulu Wae & 1 & 2 & 1 & 1 & 1 & 2 & 2 & 10 \\
\hline 18 & L. Alla Pusae & 2 & 2 & 2 & 2 & 1 & 2 & 2 & 11 \\
\hline 19 & L. Bettue & 3 & 3 & 3 & 3 & 1 & 1 & 2 & 16 \\
\hline 20 & L. Ulu Leang & 3 & 3 & 2 & 2 & 1 & 1 & 2 & 14 \\
\hline 21 & L. Ambe Pacco & 3 & 3 & 2 & 2 & 1 & 2 & 2 & 15 \\
\hline 22 & L. Burung & 3 & 3 & 1 & 1 & 1 & 2 & 2 & 13 \\
\hline 23 & L. Pangia & 2 & 3 & 2 & 2 & 1 & 2 & 3 & 15 \\
\hline 24 & L. Lompoa & 2 & 2 & 2 & 2 & 1 & 2 & 2 & 13 \\
\hline 25 & L. Bembe & 3 & 3 & 1 & 1 & 2 & 1 & 2 & 13 \\
\hline 26 & L. Timpuseng & 3 & 3 & 3 & 3 & 2 & 2 & 2 & 18 \\
\hline 27 & L. Bo'dong & 2 & 2 & 3 & 3 & 1 & 1 & 1 & 13 \\
\hline 28 & L. Bara Tedong & 3 & 3 & 2 & 2 & 1 & 3 & 2 & 16 \\
\hline 29 & L. Bulu Tengngae & 3 & 3 & 1 & 1 & 1 & 3 & 3 & 15 \\
\hline 30 & L. Bulu Kamase & 3 & 3 & 1 & 1 & 1 & 3 & 2 & 14 \\
\hline 31 & L. Lambatorang & 3 & 3 & 3 & 3 & 2 & 3 & 3 & 20 \\
\hline 32 & L. Bunga Eja & 3 & 2 & 3 & 2 & 1 & 2 & 2 & 15 \\
\hline 33 & L. Alla Berang & 1 & 1 & 1 & 1 & 1 & 1 & 1 & 7 \\
\hline 34 & L. Mandauseng & 3 & 3 & 3 & 3 & 1 & 2 & 2 & 17 \\
\hline 35 & L. Botto & 3 & 3 & 2 & 2 & 1 & 1 & 2 & 14 \\
\hline 36 & L. Pabbuno Juku & 3 & 3 & 1 & 2 & 1 & 1 & 2 & 13 \\
\hline 37 & L. Wanuae & 2 & 2 & 1 & 1 & 1 & 2 & 2 & 11 \\
\hline 38 & L. Pellenge & 3 & 3 & 2 & 2 & 1 & 1 & 1 & 13 \\
\hline 39 & L. Pucu & 1 & 1 & 1 & 1 & 1 & 1 & 1 & 7 \\
\hline 40 & L. Sampeang & 3 & 3 & 2 & 2 & 1 & 3 & 3 & 17 \\
\hline
\end{tabular}

Keterangan $:$ Ark $=$ Arkeologi, Eko $=$ Ekologi, Spel $=$ Speleogenesis, Etn $=$ Etnik, Este $=$ Estetika,dan Pub $=$ Publik.

penting sedang sebanyak 18 gua,sedangkan gua yang termasuk kategori bernilai penting rendah sebanyak 4 gua. Data di atas menunjukkan bahwa beberapa gua yang kontribusinya besar dalam rekonstruksi prasejarah Asia Tenggara, ternyata hanya termasuk dalam kategori sedang, seperti Gua Ulu Leang dan Gua Leang Burung.
Hal tersebut disebabkan karena kedua gua tersebut kurang nilainya pada variabel yang lain, meskipun nilai arkeologisnya tinggi. Di sisi lain, empat gua yang termasuk kategori bernilai penting rendah, beralasan jika dalam pengelolaannya kemudian mendapat prioritas ketiga, tentunya setelah kategori tinggi dan sedang. 
Detail nilai dari setiap variabel pada setiap gua juga dapat digunakan untuk menentukan jenis pemanfaatan setiap gua. Data di atas menggambarkan bahwa ada gua yang berpotensi untuk dimanfaatkan menjadi objek wisata massal, ada gua yang hanya berpotensi untuk pemanfaatan akademik, ada gua yang berpotensi untuk wisata minat khusus, bahkan ada gua yang berpotensi untuk wisata religi.

\section{Penutup}

Penelitian ini menyimpulkan bahwa nilai penting satu gua dengan gua lain berbeda, dan dapat diverifikasi secara ilmiah bahkan dengan angka. Tujuh variabel nilai penting beserta kriteria penilaiannya telah berhasil dipakai untuk membedakan 40 gua di dalam kompleks Leang-Leang Maros. Hasilnya adalah 18 gua yang bernilai penting tinggi, 18 gua yang bernilai penting sedang dan 4 gua bernilai penting rendah. Kesimpulan ini dapat menjadi bahan pertimbangan dalam pengelolaan guagua tersebut di masa mendatang, atau kontribusi saintifik dalam upaya konservasi arkeologi berbasis nilai penting di Indonesia.

Riset ini merupakan pekerjaan ilmiah yang sangat dibatasi oleh waktu, tenaga peneliti, dana, dan keterbatasan lain. Karena itu, di masa mendatang direkomendasikan agar kriteria penilaian lebih diluaskan, dikaji lebih dalam dan lebih ketat agar ketepatan pengelolaan dapat didekati.

\section{Ucapan Terima Kasih}

Penelitian ini dimungkinkan rampung atas dukungan dan masukandari Bapak Andi M. Said, Bapak M. Ramli, Bapak Yusriadi, Bapak Rustan, dan Bapak Iswadi. Demikian pula kepada Ibu Dewi Susanti dan Bapak M. Tang atas dukungan datanya. Kepada Bapak Lanti Sahabu dan Bapak Iwan di Leang-leang yang mengakomodasi penulis, saya sangat berterima kasih. Kepada tim lapangan: Ilham Abdullah, Febrianto, Andi Jusdi, Buhanis dan Abdullah, yang sangat bersemangat dan ikhlas, bergantian menemani penulis penelusuri 40 gua, saya haturkan terima kasih. Jogjakarta-Makassar, pengujung 2015.

\section{DAFTAR PUSTAKA}

Andrefsky Jr., William (ed.). 2008. Lithic Technology, New York. Cambridge University Press.

Anonim. 1999. Laporan Studi Kelayakan Gua-Gua Prasejarah Kawasan Bellae Kabupaten Pangkep Propinsi Sulawesi Selatan. Suaka Peninggalan Sejarah dan Purbakala Sulawesi Selatan dan Tenggara.

Anonim, 2000. Keputusan Menteri Energi dan Sumberdaya Mineral Nomor 1456 K/20/MEM/2000 tentang

Pedoman Pengelolaan Kawasan Karst.

Anonim. 2001. Laporan Pemetaan/Pengukuran Gua-Gua Prasejarah Kawasan Bellae Kabupaten Pangkep. Suaka Peninggalan Sejarah dan Purbakala Propinsi Sulawesi Selatan dan Tenggara.

Anonim. 2007. Laporan Studi Teknis Pelestarian Pengembangan Kawasan Gua-GuaPrasejarah Bellae Kabupaten Pangkep Sulawesi Selatan. Balai Peletarian Peninggalan Purbakala Makassar.

Anonim. 2007. Laporan Pemintakatan (Zoning) Kompleks Situs Gua Prasejarah Bellae, Kabupaten Pangkep. Balai Pelestarian dan Peninggalan Purbakala Makassar.
Anonim, 2012. Undang-undang Republik Indonesia Nomor 11 Tabun 2010 Tentang Cagar Budaya, Jakarta, Kementerian Pendidikan dan Kebudayaan Republik Indonesia.

Aubert, M., A, Brumm, M. Ramli, T. Sutikna, E. W. Saptomo, B. Hakim, M. J. Morwood, G. D. van den Berg, I. Kinsley, A. Dosseto (2014). Pleistocene cave art from Sulawesi, Indonesia. Journal of Nature. 514 :223-227.

Brumm, Adam, dkk., 2012, The 2011 Excavations at Leang Burung 2 Rockshelter in South Sulawesi, Indonesia. Laporan penelitian. Tidak Terbit.

Bullock, J.A., 1966, The Ecology of Malaysian Caves. Malay. Nat. J. 19: Hal. 57-63.

Darvill, Timothy. 1995. "Value System in Archaeology". Dalam Malcolm A. Copper et al. Managing Archaeology. London and New York: Routledge.

Di Lello, A., 2002. A Use Wear Analysis of Toalian Glossed Stone Artifacts rom South Sulawesi, Indonesia. Indo-Pacific Prehistory Association Bulletin 2 (6), pp: 45-50. 
Duli, Akin dan Muhammad Nur, 2016. Prasejarah Sulawesi, Makassar. Fakultas Ilmu Budaya Unhas Press.

Forestier, Hubert, 2007, Ribuan Gunung, Ribuan Alat Batu, Prasejarah Song Keplek, Gunung Sewu, Jawa Timur. Jakarta Selatan. Kepustakaan Populer Gramedia.

Glover, I. C. (1976). Ulu Leang cave, Maros: A preliminary sequence of post-Pleistocene cultural developments in South Sulawesi. Archipel 11, pp: 113-154.

Glover, I. C. (1984). Leang Burung 2: An Upper Palaeolithic rock shelter in South Sulawesi, Indonesia. Dalam Pieter van De Velde (eds), Prehistoric Indonesia, pp: 327-74. Dordrecht: Foris.

Goodwin, R.E., 1979. The Bats of Timor: Syntematics and Ecology.Bull. Amer. Mus. Nat. Hist. 163: 1-122.

Heekeren, H. R. van, 1972. The Stone Age of Indonesia. $2^{\text {nd }}$ ed. The Hague Martinus Nijhoff.

Nugroho, Wicaksono Dwi. 2006. Model Pengelolaan Kawasan Wisata Budaya Terunyan, Kajian melalui perspektif Cultural Resource Management. Tesis Magister Program Studi Arkeologi Fakultas Ilmu Budaya, Universitas Gadjah Mada. Tidak Terbit.

Nur, Muhammad. 2009. Pelestarian Kompleks Gua Leang-leang, Kabupaten Maros, Sulawesi Selatan. Tesis Magister Program Studi Arkeologi Fakultas Ilmu Budaya, Universitas Gadjah Mada. Tidak Terbit.
Nur, Muhammad,2013. Prasejarah Maros. Laporan Penelitian Tahun Anggaran 2013. Tidak Terbit.

Odum. Eugene P., 1994. Dasar-Dasar Ekologi. Yogyakarta. Gadjah Mada University Press.

Pearson, Michael dan Sharon Sullivan. 1995. Looking After Heritage Places: The Basic of Heritage Planning for Managers, Landowners and Adiministrators. Melbourne: Melbourne University Press.

Rustam Awat. 2007. "Alternatif Pengembangan Sumberdaya Budaya di Keraton Buton, Sulawesi Tenggara”. Tesis. Yogyakarta: Universitas Gadjah Mada.

Sarasin, Paul and fritz, 1905.Reisen in Celebes. Zweiter band. Wiesbaden: C.W. Kreidel's Verlag.

Schiffer, Michael B. \& George J. Gumerman. 1977. Conservation Archaeology, AGuide for Cultural Resources Management Studies . London: Academic Press New York San Fransisco.

Simanjuntak, Truman, (ed.), 2008. Austronesian in Sulawesi. Depok-Indonesia. Center for Prehistoric and Austronesia Studies.

Supriadi. 2008. Pemanfaatan kompleks gua prasejarah Bellae. Tesis Magister Program Studi Arkeologi Fakultas Ilmu Budaya, Universitas Gadjah Mada. Tidak Terbit.

Whitten, Anthony. J., 1987. Ekologi Sulawesi. Yogyakarta, Gadjah Mada University Press. 